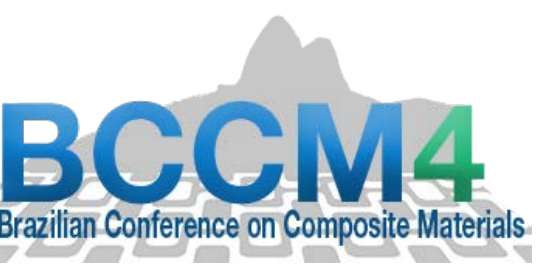

\title{
EFFECT OF THE RESIDUAL FINE ELEMENTS AND CONTRIBUTION ON FRESH PROPERTIES OF SELF-LEVELING MORTARS
}

\author{
Henrique Duarte Sales Carvalho ${ }^{(1)}$, Janaíde Cavalcante Rocha ${ }^{(1)}$ and Malik Cheriaf ${ }^{(1)}$ \\ (1) Department of Civil Engineering, Universidade Federal de Santa Catarina, UFSC, Brazil
}

https://doi.org/10.21452/bccm4.2018.02.17

\begin{abstract}
The self-leveling mortar is a fluid product that has as a low viscosity and high fluidity. This building material that requires no vibration and leveling, having very low thickness ( $30 \mathrm{~mm}$ ). The purpose of this study is to evaluate fresh properties of self-leveling SLU using three byproducts: bottom-ashes, fine elements of quarry limestone and fine elements from recycledconcrete-waste. Portland Cement OPC was partially replaced by 0,10, 15 e 20\% of fines. The water/binder was maintained constant at 0.50 and mix proportion 1:2 cement and sand (by weight) was used. Fresh properties were examined: plastic shrinkage, curling and heat measurements using a semi-adiabatic calorimeter. A superplasticizer (polycarboxylate) was used to assure a fluidity. During drying ( $\mathrm{HR}=50 \%$ ) a mass loss was monitored. To the same cement content fine from bottom-ash acted efficiently to reduce a shrinkage. The curling phenomenon is high, with more than 1.70 for mortars based on fine from recycled-concretewaste. Higher early curling was obtained for mortars with quarry limestone. A good performance could be assured with ternary mixes with bottom ashes (curling less than $8 \mathrm{~mm}$ ). Self-leveling mortar systems with more than $20 \%$ of fine resulted negative effect on segregation and bleeding, so not recommended to self-leveling mortar purposes.
\end{abstract}

KEYWORDS: bottom ashes, fine from CDW aggregates, self-leveling mortars, fresh properties, shrinkage.

\section{INTRODUCTION}

Self-leveling mortars are characterized by their ability to spread quickly and self level, without the need of manual or mechanical intervention. The homogeneity of these compounds is necessary to ensure the endurance and durability characteristics of the final product, therefore, it is imperative that the mixture exhibits high stability [1]. The most important properties in a self-leveling mortar system, considering its viability and its final characteristics are: self leveling, low viscosity, fast hardening, fast setting time, fast rate of strength, dimensional stability, high final compressive strength, surface durability and a strong adhesion 
to the substrate. To meet all these requirements, self-leveling mortars often contain a wide variety of organic and inorganic compounds [2].

The use of self-leveling mortar system offers environmental and economic advantages. Among these advantages, it is possible to highlight the use of residues from other processes, such as a source of admixtures to replace part of the Portland cement, and to improve the characteristics of the final product, mainly the rheological properties [3]. In Spain, natural coarse aggregates may be substituted by Recycled Concrete Waste (RCW) to concrete production in proportions of $20 \%$ to $100 \%$ [4, 5], however the fine fraction of RCW is not allowed. The greater difficulty in the use of fine RCW is related to its high absorption of water [6]. In order to ensure selfleveling behaviour, a greater amount of fine is required to achieve an effective fluidity [7]. Therefore, the use of the fine portion of this residue can be a sustainable solution to manufacture coarse recycled aggregate from recycling plants.

Mortar and concrete are porous materials, which are susceptible to volume variations due to shrinkage during hydration and drying. In particular, the development of cement based selfleveling mortars still limited because of problems such as cracking or warping of corners $[8,9]$. These cracks are caused by shrinkage occurring from drying. The shrinkage in self-leveling systems is influenced by the high content of fine particles required to achieve effective fluidity $[10,11]$. The fine particles demand more water, due to the greater specific surface area, increasing the tendency of greater volumetric variation during drying.

The Coal Bottom Ash (CBA) when used as a substitute for the natural fine aggregate can improve internal curing, and reduce capillary forces, hydration temperature and consequently the shrinkage in concretes [12]. Concrete mixtures which incorporate bottom ash as fine aggregates for partial or total replacement of natural sand exhibit better dimensional stability. The structure of porous particle in bottom ash was beneficial for decreasing shrinkage in concrete samples. At the age of 180 days, concrete mixtures with bottom ashes FBC 2 (50\%), FBC $3(75 \%)$ and FBC 4 (100\%) presented 21.79\%, 34.62\% and 37.17\%, respectively, demonstrating lower shrinkage values by drying compared to the control mixture [13].

In this context, the present study aims to produce self-leveling mortars using fines of residues (CBA and RCW) as partial substitutes for Portland cement and contribute to sustainable development.

\section{MATERIALS}

The materials used in the research were Portland Cement CP V - ARI (Hight initial strength), limestone powder (LP), recycled concrete waste (RCW) and coal bottom ash (CBA) fines. As natural aggregate, sand was used (Dmáx=2 $\mathrm{mm}$ ) and a superplasticizer (SP) admixtures based on polycarboxylate.

\section{METHOD}

\subsection{Material characterization}

The material characterization tests were carried out according to the procedures established in Brazilian technical standards. The specific gravity of the fines and the sand was determined according to the standard ABNT NBR NM 52/2009. The specific gravity of the Portland cement was determined according to the standard ABNT NBR NM 23/2001.

The specific area of the Portland cement and its fineness modulus were determined according to the standard ABNT NBR NM 76/1998. 
The grain size distribution of the sand was determined according to the standard ABNT NBR NM 248/2003. Particle sizes were determined on the fines (LP, RCW and CBA) by laser granulometry using the Microtrac S3500 equipment. Chemical analysis of fine materials (CP, LP, RCW and CBA) were analysed by energy dispersive X-Ray Spectrometer 700 (EDX 700) Shimadzu equipment.

\subsection{Mortar study}

The fines (LP, RCW and CBA) were used as partial replacing of the Portland cement CP V ARI, in content of $10 \%, 15 \%$ and $20 \%$, by volume, due to difference between the specific gravity of the fines. The sand and fines were added to the dry condition.

Initially, experiments were carried out to evaluate the consistency properties of the mortar in the fresh state. For this purpose, the mortar was dosed to determine the range of admixtures superplasticizer and the content of fines. All mixes were prepared with cement and sand ratio of 1:2 ratio (cement / aggregate) and a w/c (water / cement) constant at 0.5.

Once tests at the fresh state were conducted and mortars with satisfactory fluidity and cohesion properties for self-leveling systems were choosen, tests were carried out in the hardened state to evaluate the heat of hydration, drying shrinkage and curling, aiming to identify indicators of durability.

\subsection{Flow value}

The flowability was measure using a mini-cone flow. Chemical admixtures consumption was determined trough to flow test (spreading) fixed by 24 and $27 \mathrm{~cm}$, to evaluate a flowability. The tests were performed shortly after preparation of the mixtures. After removal of a mini cone, the flow was evaluated over a glass suport marked with $20 \mathrm{~cm}, 25 \mathrm{~cm}$ and $30 \mathrm{~cm}$ diameters. The final value was considered as the mean between two perpendicular measurements of spreading.

The self-leveling mortars chosen were those behaving cohesively without signs of segregation or bleeding and with a good visual appearance. The selected mortars were identified according to the material used and the cement replacement content (Table 1).

Table 1: Identification of self-leveling mortars and mixes proportions.

\begin{tabular}{|c|c|c|c|c|c|}
\hline \multirow{2}{*}{ Identification } & \multirow{2}{*}{$\begin{array}{l}\text { Cement } \\
\text { Consumption } \\
\left(\mathbf{m}^{3}\right)\end{array}$} & \multirow{2}{*}{$\begin{array}{l}\text { Cement } \\
\text { Replacement } \\
\text { Content }\end{array}$} & \multicolumn{3}{|c|}{ Fines Content (\%) } \\
\hline & & & $\mathbf{L P}$ & RCW & CBA \\
\hline FC 10 & 536.4 & & 10 & & \\
\hline $\mathrm{FC}+\mathrm{RCD} 10$ & 534.2 & $10 \%$ & 5 & 5 & \\
\hline $\mathrm{FC}+\mathrm{CBA} 10$ & 530.1 & & 5 & & 5 \\
\hline
\end{tabular}




\begin{tabular}{llllll} 
FC + RCD +CBA 10 & 529.4 & & 5 & 2.5 & 2.5 \\
\hline FC 15 & 527.9 & & 15 & & \\
FC + RCD 15 & 517.9 & & 7.5 & 7.5 & \\
FC + CBA 15 & 528.4 & $15 \%$ & 7.5 & & 7.5 \\
FC + RCD + CBA 15 & 516.3 & & 7.5 & 3.75 & 3.75 \\
\hline
\end{tabular}

\subsection{Temperature of hydration of mortars}

A semi-adiabatic calorimeter was used to evaluate the temperature evolution of self-leveling mortars. The mortars were placed, still under the fresh state, in a cylindrical container of polystyrene. Thereafter, the container was placed in a thermal box. Temperature measurements from the samples were collected through thermocouples and processed into a Hewlett-Packard data logger, model 34970A, connected to a computer for data storage, with readings at every 20 seconds.

\subsection{Drying shrinkage}

In order to evaluate displacements of the corners (curling), an experiment on plates was carried out. Following the procedure adopted by other researchers [9, 14] that evaluated the drying shrinkage in self-leveling mortars.

Tests to measure curling and the linear shrinkage of self-leveling mortars were performed simultaneously with the same sample. The displacement values were verified by Linear Variable Differential Transformer (LVTDs) and processed automatically through a data acquisition equipment (Data Logger), which was connected to a computer for data storage (Figure 1). After the mortar had started to hardening (according to the results of evolution of hydration temperature of mortars), equipments for linear shrinkage and curling data collection were connected for a period of 5 consecutive days (Fig.1). The temperature $\left(23 \pm 2{ }^{\circ} \mathrm{C}\right)$ and relative humidity $(60 \% \pm 5 \%)$ were monitored during the test period.

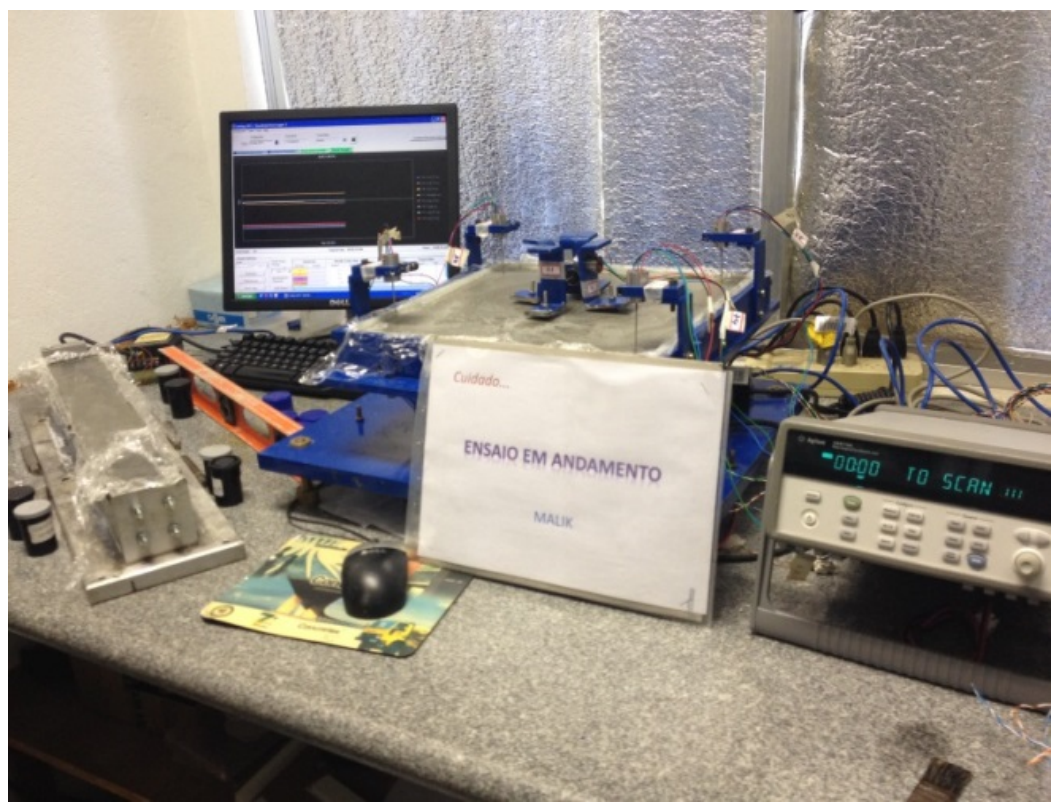

Figure 1: Experimental set up for curling. 


\section{RESULTS AND ANALYSIS}

\subsection{Characterization}

The physical and chemical properties of cement and fines materials are shown in Table 2.

Table 2: Chemical compositions and physical properties of materials.

\begin{tabular}{|c|c|c|c|c|}
\hline Oxides & $\begin{array}{l}\text { Cement } \\
\text { Portland } \\
\text { CP V }\end{array}$ & $\begin{array}{l}\text { Limestone } \\
\text { Filer }\end{array}$ & $\begin{array}{l}\text { Fines } \\
\text { CBA }\end{array}$ & $\begin{array}{l}\text { Fines } \\
\text { RCW }\end{array}$ \\
\hline \multicolumn{5}{|c|}{ Chemical analysis (\%) } \\
\hline \multicolumn{5}{|c|}{ Oxides } \\
\hline $\mathrm{CaO}$ & 74.795 & 54.788 & 1.733 & 41.202 \\
\hline $\mathrm{SiO}_{2}$ & 12.303 & 4.321 & 40.819 & 29.048 \\
\hline $\mathrm{Al}_{2} \mathrm{O}_{3}$ & & & 37.458 & \\
\hline $\mathrm{Fe}_{2} \mathrm{O}_{3}$ & 4.458 & 0.775 & 5.713 & 9.805 \\
\hline $\mathrm{K}_{2} \mathrm{O}$ & 2.071 & 0.472 & 5.197 & 3.905 \\
\hline $\mathrm{SO}_{3}$ & 1.984 & & & \\
\hline $\mathrm{TiO}_{2}$ & & & & 1.447 \\
\hline $\mathrm{CO}_{2}$ & 3.243 & & 6.674 & 13.22 \\
\hline \multicolumn{5}{|c|}{ Physical properties } \\
\hline $\begin{array}{l}\text { Specific gravity } \\
\left(\mathrm{Kg} / \mathrm{m}^{3}\right)\end{array}$ & 3040 & 2680 & 1920 & 2460 \\
\hline $\begin{array}{l}\text { Blaine Fineness } \\
\left(\mathrm{m}^{2} / \mathrm{Kg}\right)\end{array}$ & 505 & 228 & 218 & 502 \\
\hline
\end{tabular}

Only the fines from bottom ash presented aluminum in a significant amount (37\%), in contrast the $\mathrm{CaO}$ content $(1.7 \%)$ was much lower than the other materials. The bottom ash, class $\mathrm{F}$, showed the lowest specific gravity, probably due to its high internal porosity.

The results for granulometric analysis of the aggregate were: characteristic maximum dimension of $1.2 \mathrm{~mm}$, characteristic minimum dimension of $0.075 \mathrm{~mm}$ and fineness modulus of 1.39. Approximately $13 \%$ of the natural sand showed grains inferior to $0.15 \mathrm{~mm}$.

The results of laser granulometry showed that the finest addition was the LP, with all grains less than $50 \mu \mathrm{m}$. The addition with the largest grain sizes was CBA, with all grains less than $0.15 \mathrm{~mm}$. All grain-sizes of FC and RCW were less than $0.075 \mathrm{~mm}$, while approximately $30 \%$ of the grains of CBA were larger.

\subsection{Flow value}

The results of flowing tests in relation to SP additive, content for self-leveling mortars with $10 \%$ and $15 \%$ of substitution are presented in Figure 2 and 3, respectively. 


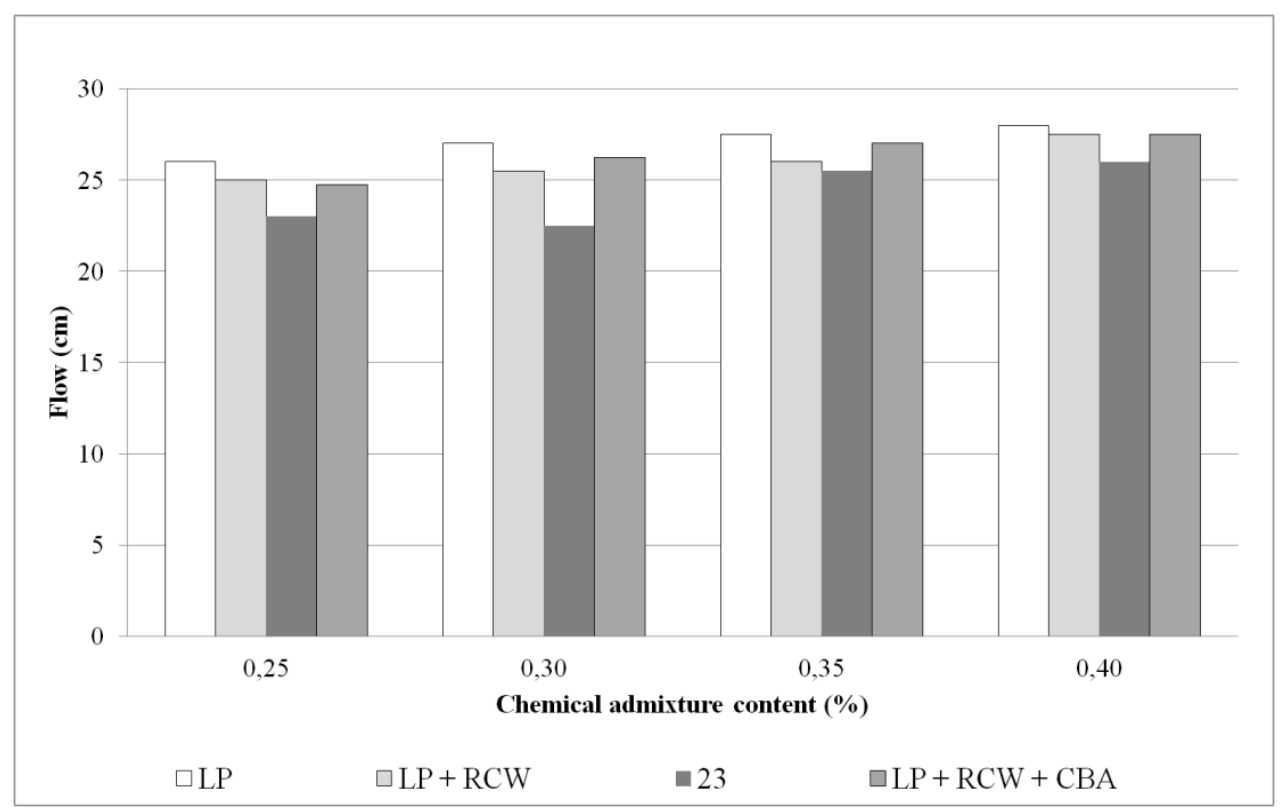

Figure 2: Self-leveling mortar flow values results - 10\% of fine replacement.

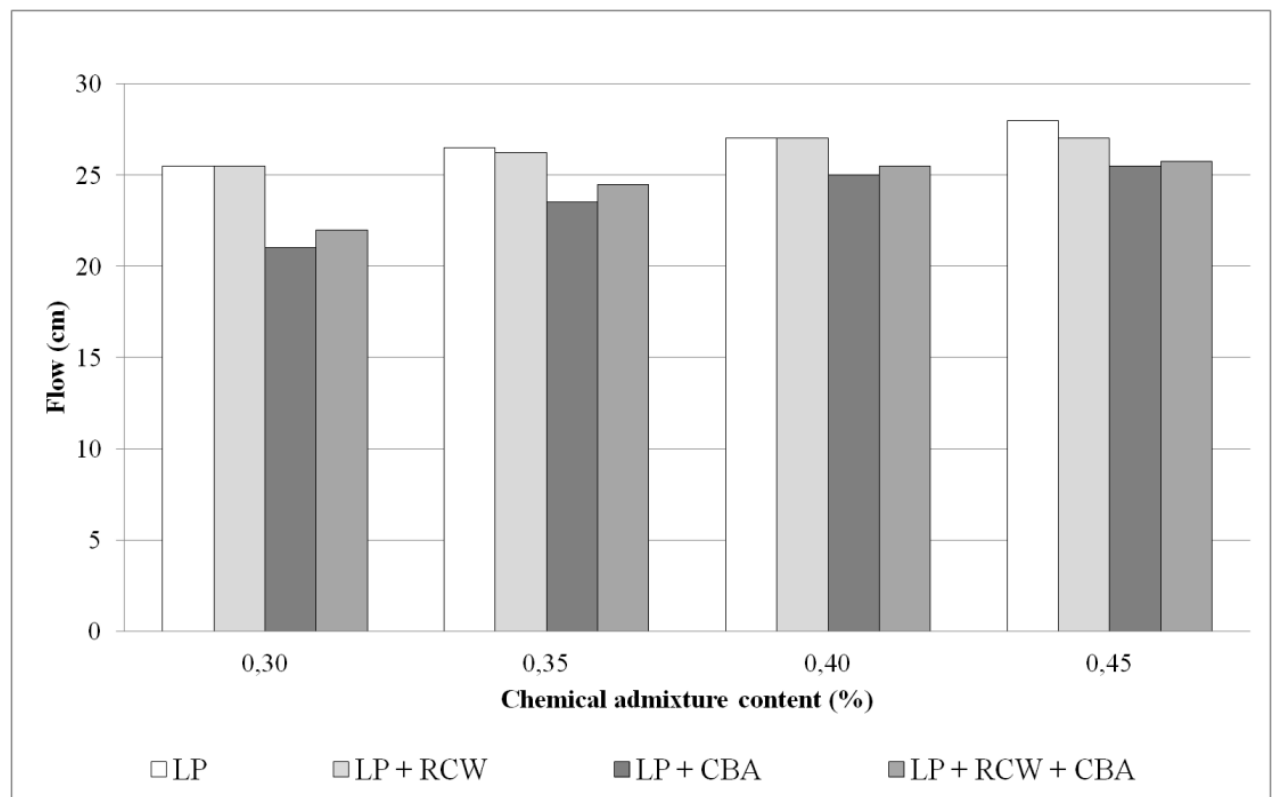

Figure 3: Self-leveling mortar flow values results- a15\% of fine replacement.

The maximum content of the SP chemical admixture used was $0.40 \%$, above which the flow of the mortars did not change significantly. In chemical admixtures, most of the mixtures with $0.45 \%$ and $0.50 \%$ showed signs of bleeding and /or segregation.

It was verified that the flow decreased with the increase of the content of fines, in all of the mixes analyzed. The same results were found by other researchers $[10,15]$. The results can be explained by the increase of the fineness and the specific surface area of the fines, because with the increase of the fine content it becomes necessary more water to wet the surface of the particles and to maintain the same fluidity.

Mixes with $20 \%$ cement substitution (from cements to the fines) were also tested, in the same manner as mixtures with $10 \%$ and $15 \%$ substitution. However, samples composed with LP + CBA and LP + CBA + RCW presented segregation, in addition to providing lower scattering values. Thus, the scattering results for substitution contents of $20 \%$ were not considered satisfactory. 
The scattering results of the selected mortars with the respective additives content are summarized in Table 3.

Table 3: Chosen Mortars.

\begin{tabular}{lllc}
\hline Identification & $\begin{array}{l}\text { Additive } \\
\text { Content (\%) }\end{array}$ & $\begin{array}{l}\text { Flow } \\
\text { (cm) }\end{array}$ & $\begin{array}{l}\text { Cement } \\
\text { Replacement } \\
\text { Content (\%) }\end{array}$ \\
\hline FC 10 & 0.25 & 26.0 & \\
FC + RCD 10 & 0.35 & 26.5 & $10 \%$ \\
FC + CBA 10 & 0.40 & 26.0 & \\
FC + RCD + CBA 10 & 0.30 & 26.25 & \\
\hline FC 15 & 0.30 & 25.5 & \\
FC + RCD 15 & 0.30 & 25.5 & $15 \%$ \\
FC + CBA 15 & 0.40 & 25.0 & \\
FC + RCD + CBA 15 & 0.40 & 25.5 & \\
\hline
\end{tabular}

\subsection{Temperature of hydration of mortars}

In order to determine the initial setting time of mortar the points of the curve were chosen where the gradual increase in temperature began. To determine the amount of time required to reach the maximum temperature, the points with the peak temperature were selected in the graph. The results are shown in Figures 4 and 5 for $10 \%$ and $15 \%$ substitution, respectively.

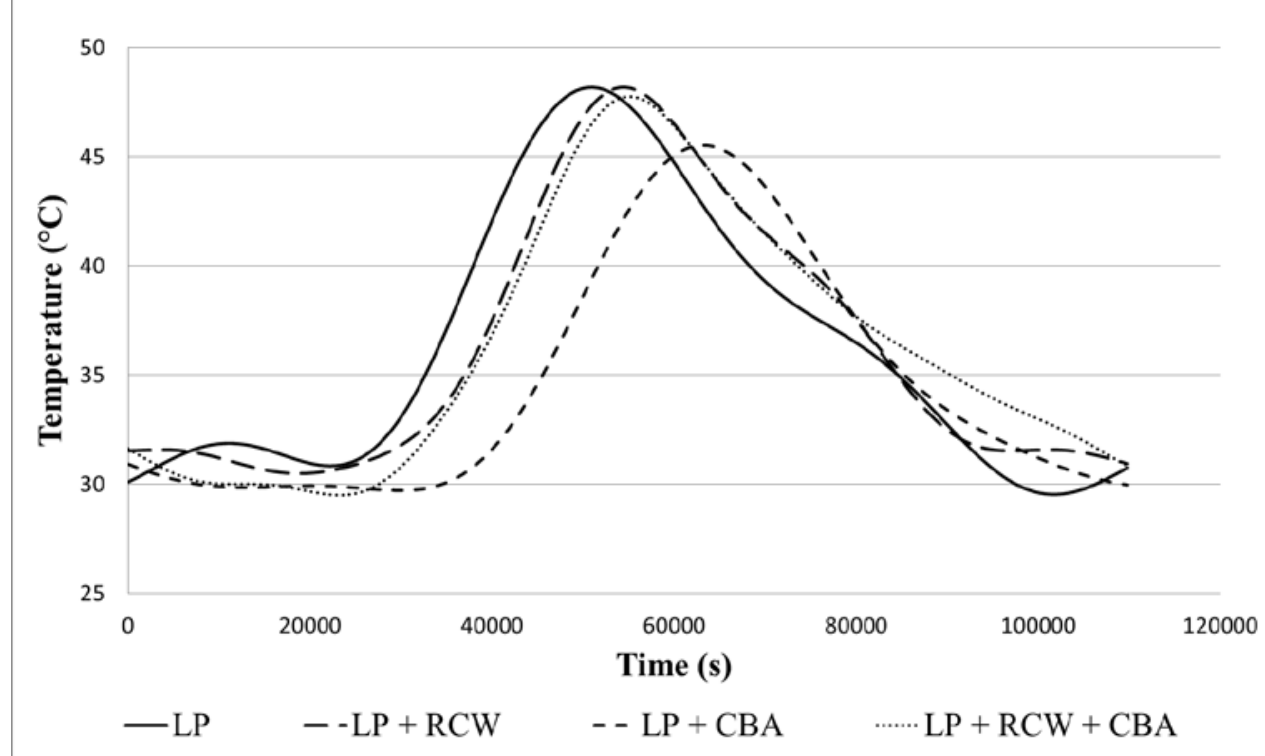

Figure 4: Evolution of the Temperature Versus Time for Mortar With 10\% Replacement. 


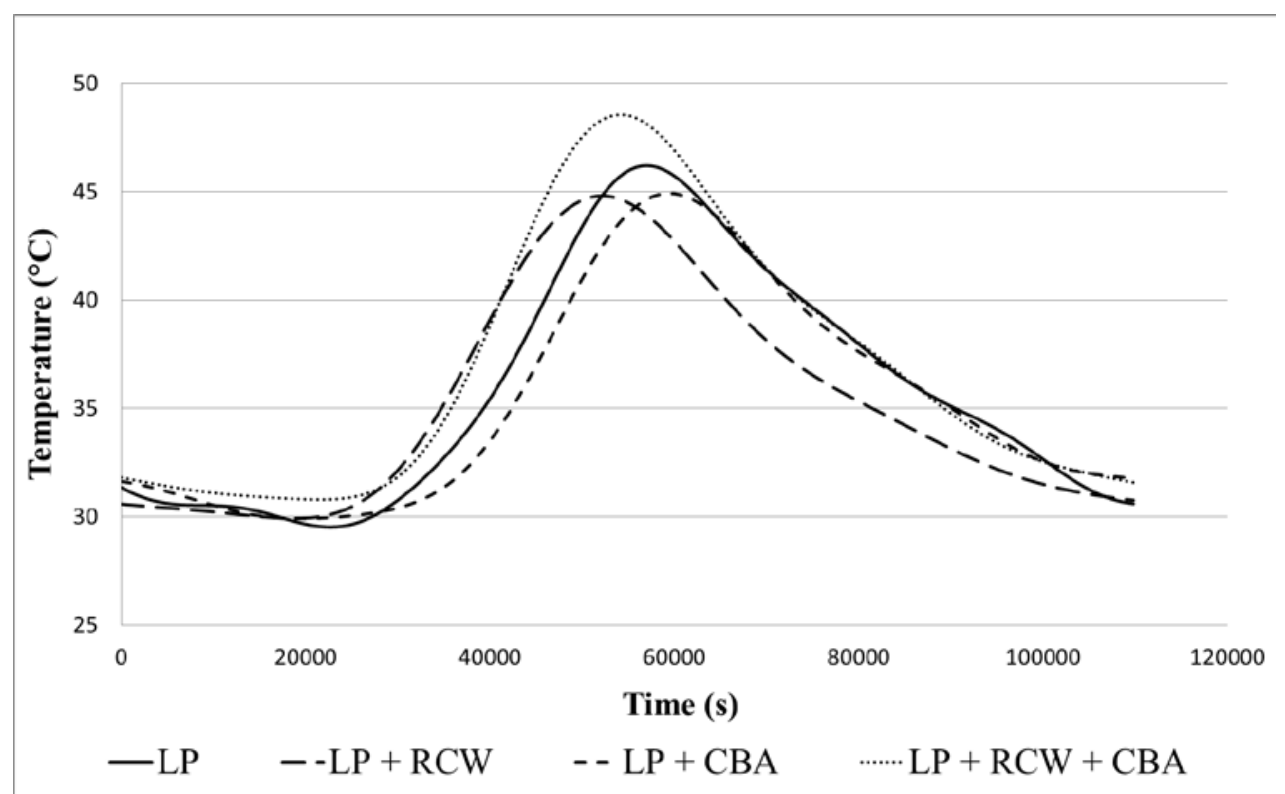

Figure 5: Evolution of the Temperature Versus Time for Mortar With 15\% Replacement.

For $10 \%$ of substitution, the LP + CBA 10 mixes presented the highest time for initiation of acceleration of the hydration reactions (approximately 8 hours). This fact occurred due to the higher content of SP chemical admixture used to achieve the required flow. The other mixes showed start times of setting of the mortar varying between 5 and 6 hours, approximately.

For mortars with a $15 \%$ substitution, all samples showed shorter initial setting times than the reference (FC 15). The mortars LP + CBA 15 and LP + RCW 15 presented the lowest maximum temperatures. Although the maximum temperature difference between all mixtures produced has been small $\left( \pm 30^{\circ} \mathrm{C}\right)$, a mixture with the lowest maximum temperature may help reduce shrinkage in self-leveling mortars. Lower temperatures during the hydration process tend to reduce the amount of water that evaporates, and consequently the dimensional variation tends to decrease.

\section{Dimensional variation (Linear shrinkage)}

Results for linear shrinkage are shown on Figure 6. 


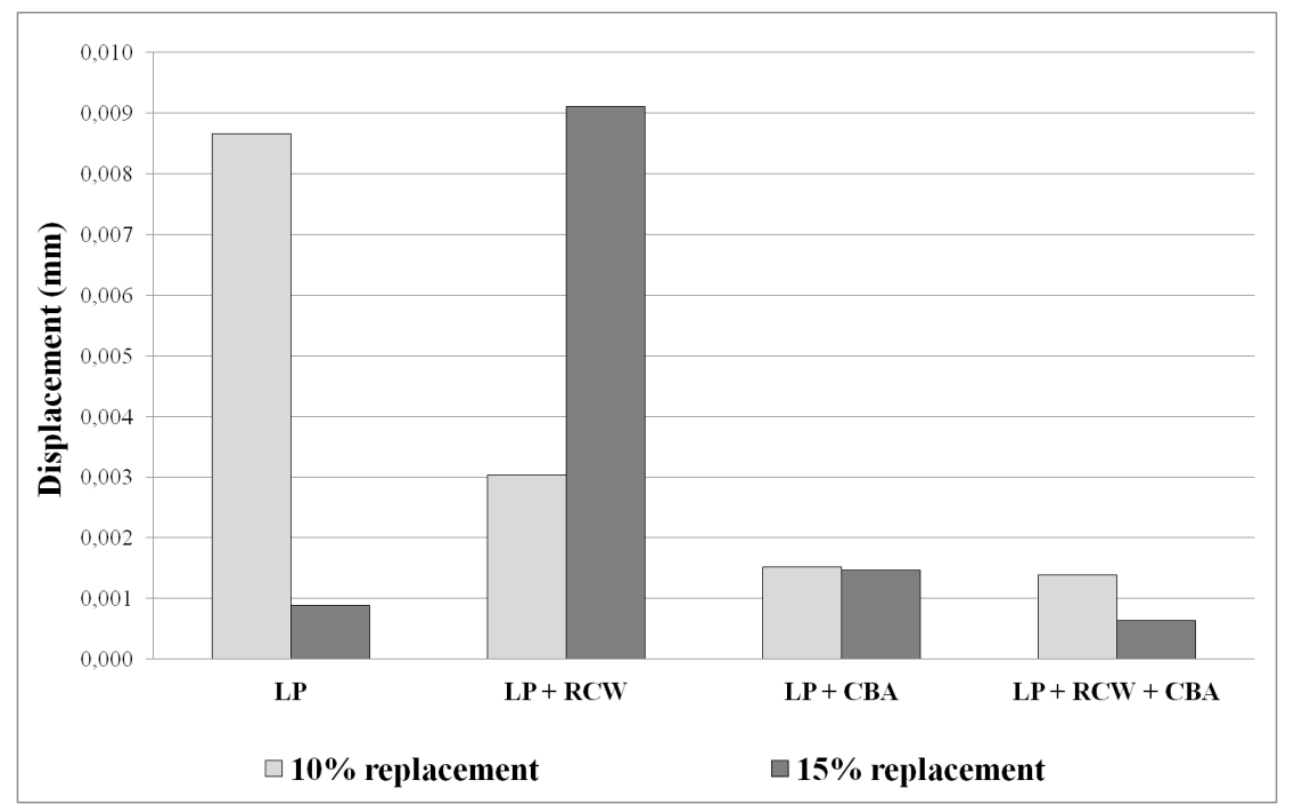

Figure 6: Linear shrinkage results.

For the mortars with $10 \%$ of substitution, all of the mixes with recycled fines were more efficient than the reference, since they presented smaller displacements. However for $15 \%$ of substitution, the mortar LP + RCW 15 presented the worst result of all samples tested. Furthermore, the mortar LP + RCW + CBA 15 presented the smallest linear shrinkage shifts $(0.006 \mathrm{~mm})$ of the eight mixtures analyzed. The LP + CBA mixtures did not present great displacement variations with the increase in the content of fines (10\% to $15 \%)$. Based on the results, it was possible to conclude that the mixtures LP + CBA and LP + RCW + CBA presented good results for both percentages of substitutions tested (10 and 15\%).

\section{Dimensional stability (curling)}

The average values of the final displacements due to the curling phenomenon generated in self-leveling mortars produced are summarized in the bar graph (Figure 7).

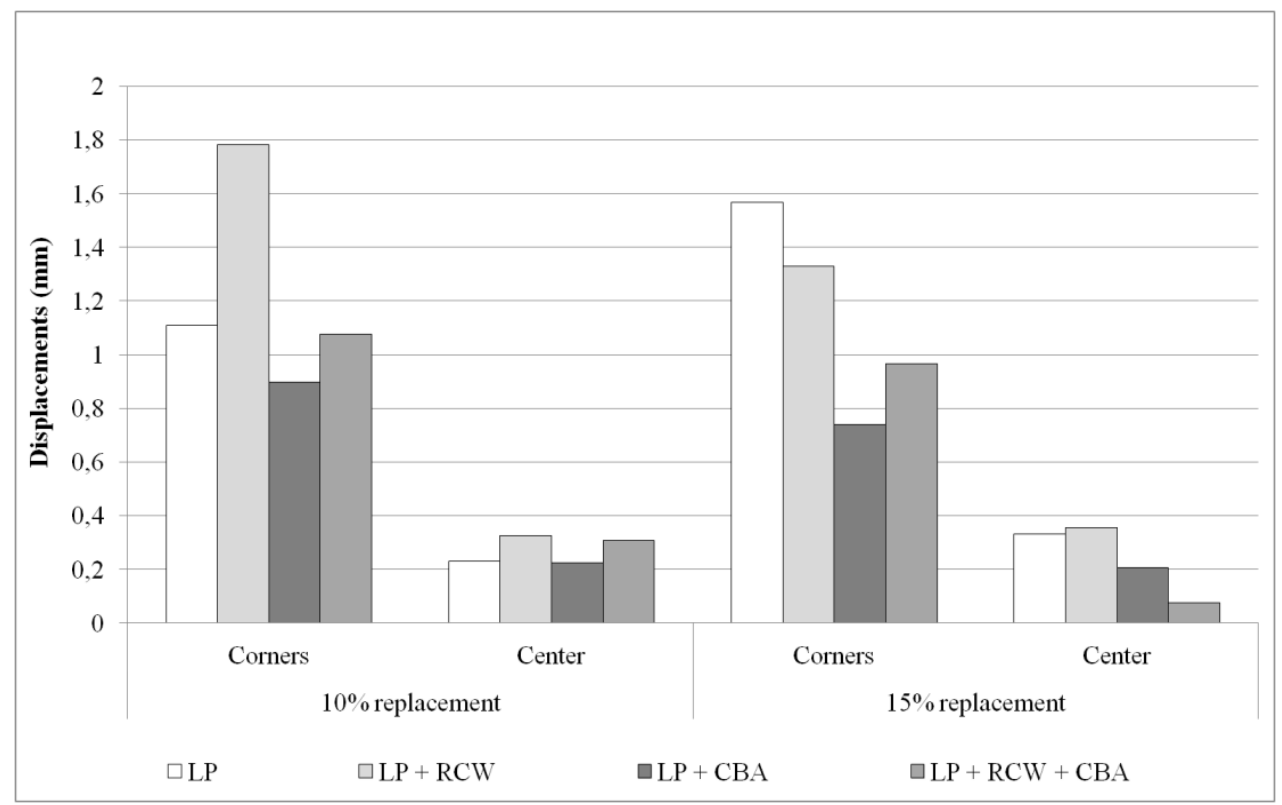

Figure 7: Average displacement in the corners and centers of the plates. 
As can be observed, only the sample LP + RCW 10 (10\% of replacement of OPC) presented values of median displacement of the corners, greater than the reference (FC). For $15 \%$ of substitution, all the self-leveling mortars were more efficient than the reference and the sample LP + CBA 15 presented the best result of all mortars produced. It was possible to identify a reduction in the displacement of corners results, with an increase of the fine content, except for the reference mortar.

The dimensional variations due to the drying process of the plates resulted in ascending curves, which are predominantly more pronounced over the corners (curling) [9]. The self-leveling mortar FC + CBA 15 achieved $0.74 \mathrm{~mm}$ of mean displacement at the corners for 130 hours of test (Figure 8).

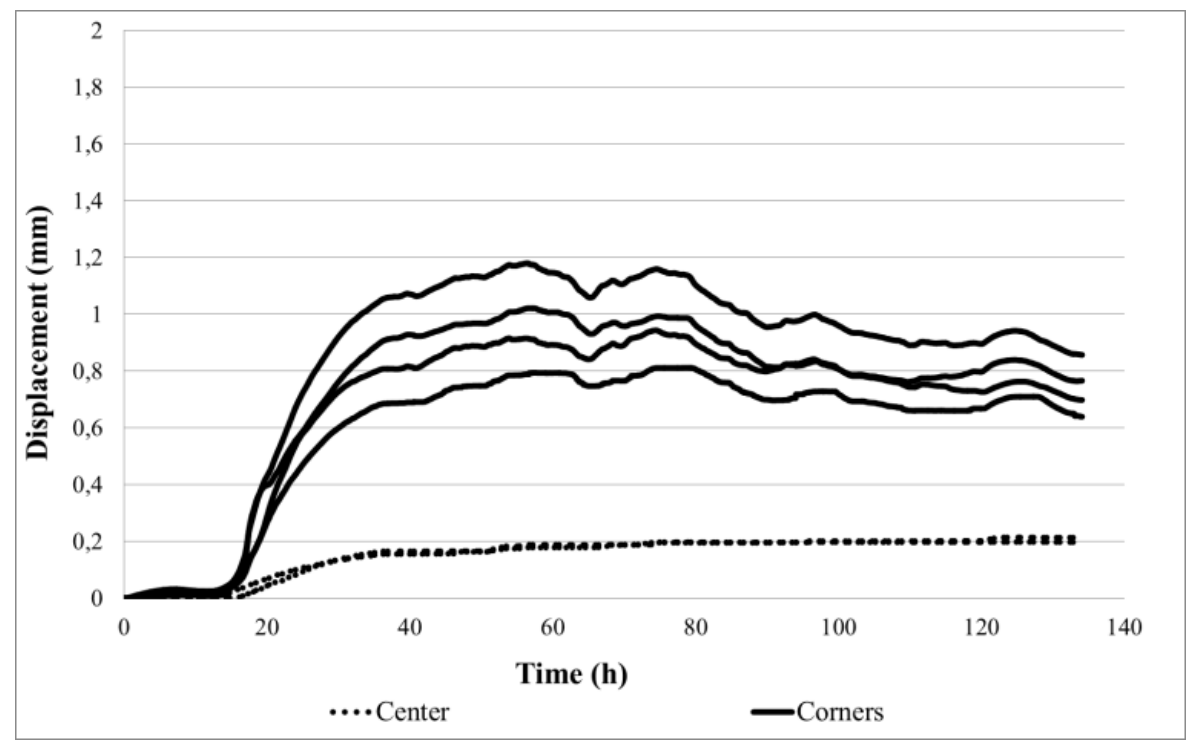

Figure 8: Curling results for self-leveling mortar LP + CBA 15 mixes .

The lowest values of shrinkage are related to the effect of internal curing as a function of the addition bottom ash. The physical characteristics of bottom ash (high porosity) confer a higher initial water absorption. As time proceeds the water absorbed initially is gradually released during the drying process of the mortar. Therefore, the internal relative humidity of the mortar undergoes minor variations and the drying shrinkage can be reduced [13, 16]. Furthermore, mixes with lower maximum hydration temperatures (LP + CBA 15) might reduce water evaporation and thus the shrinkage tends to be lower [12].

It was visually verified that none of the samples produced presented cracks. Higher shrinkage values can give rise to cracks and, consequently, contribute for penetration of external aggressive agents that degrades the material, such as salts, acids, microorganisms, water, among others. The influence of these external agents on the self-leveling mortar tends to reduce the durability of the material.

\section{CONCLUSIONS}

In the self - leveling mortars analyzed in this present study it was possible to verify the viability of application of the recycled fines (RCD and CBA) in replacement of 10 and 15\% of cement substitution, and maximum SP chemical admixtures contents of $0.40 \%$ of the binder (wt\%).

- Mortars based on RCW demonstrated scatter values similar to those of the reference mixture (LP), in addition to a adequate consistency and good visual appearance. 
- Mortars composed of CBA as fine elements demonstrated more efficiency in combating bleeding, despite of reducing the flow in contrast to the reference. Therefore, the use of LP + CBA in binary binder compositions required higher amounts of SP chemical admixtures.

- Mortars formulated with CBA as fines were more prone to segregation for higher chemical admixtures contents $(\geq 0.45 \%)$ of the binder mass and for higher binder substitution contents $(\geq 20 \%)$;

- The ternary mixes (LP + RCW + CBA) exhibits similar flowability to the reference (LP).

The main goal of the present research was to evaluate the shrinkage, as it is considered one of the main problems generated in self-leveling mortars. Data from the curling effect and maximum hydration temperature indicated that the LP + CBA 15 mortar presented the most efficient results. The LP + CRW + CBA 15 sample was the most efficient for the linear shrinkage test. In this way, it was possible to conclude that the use of bottom ash fines (CBA) reduces the drying shrinkage. Finally, we can conclude that the mortars LP + CBA 15 and LP + RCW + CBA 15 were the most efficient mixes.

\section{ACKNOWLEDGEMENTS}

The authors gratefully acknowledge the National Council for Scientific and Technological Development (CNPq), CAPES, for financial support of this work.

\section{REFERENCES}

[1] Mehdipour, I.; Razzagui,M.S.; Amini, K.; Shekarchi, M. 'Effect of mineral admixtures on fluidity and stability of self-consolidating mortar subjected to prolonged mixing time'. Construction and Building Materials, 40, p. 10. 29-1037, 2013.

[2] Seifert, S.; Neubauer, J.; Neunhoeffer, F.G. 'Spatially resolved quantitative in-situ phase analysis of a self-leveling compound'. Cement and Concrete Research, 42, p. 919-927, 2012.

[3] Alrifai, A.; Aggoun, S.; Kadri, A.; Kenai, S.; Kadri, E.H. 'Paste and mortar studies on the influence of mix design parameters on autogenous shrinkage of self-compacting concrete'. Construction and Building Materials, 47, p. 969-976, 2013.

[4] ACHE, 'Use of recycled aggregates for production of structural concrete'. Asociación Científica del Hormigón Estructural, Madrid, 2005 (in Spanish). AENOR, EHE-08 regulation of structural concrete, Spain, 2008 (in Spanish).

[5] Zhao, Z,; Remond, S.; Damidot, D.; Xu, W. 'Influence of fine recycled concrete aggregates on the properties of mortars. Construction and Building Materials', 81, p.179-186, 2015.

[6] López, D.C.; Fonteboa B. G.; Brito J.; Abella, F. M.; Taboada, I.G.; Silva, S. 'Study of the rheology of self-compacting concrete with fine recycled concrete aggregates'. Construction and Building Materials, 96, p. 491-501, 2015.

[7] Georgin, J.F.; Ambroise, J.; Péra, J.; Reynouard, J.M. 'Development of self-leveling screed based on calcium sulfoaluminate cement: modelling of curling due to drying'. Cement \& Concrete Composites, 30, p. 769-778, 2008.

[8] LE-Bihan, T.; Georgin, J.F.; Michel, M.; Ambroise, J.; Morestin, F. 'Measurements and modeling of cement base materials deformation at early age: The cause of sulfo-aluminous cement'. Cement and Concrete Research, 42, p. 1055-1065, 2012.

[9] Benabed, B. Kadri, E. H. Azzouz, L. Kenai, S. 'Properties of self-compacting mortar made with various types of sand'. Cement \& Concrete Composites, 34, p.1167-1173, 2012. 
[10] Onishi, K.; Bier, T. 'Investigation into relations among technological properties, hydration kinetics and early age hydration of self-leveling underlayments'. Cement and Concrete Research, 40, p. 1034-1040, 2010.

[11] Andrade, L.B.; Rocha, J.C.; Cheriaf, M. 'Influence of coal bottom ash as fine aggregate on fresh properties of concrete'. Construction and Building Materials, v. 23, p. 609-614, 2009.

[12] Rafieizonooz, M.; Mirza, J.; Salim, M. R.; Hussin, M. W.; Khankhaje, E. 'Investigation of coal bottom ash and fly ash in concrete as replacement for sand and cement'. Construction and Building Materials, 116, p. 15 - 24, 2016.

[13] Péra, J.; Ambroise, J. 'New applications of calcium sulfoaluminate cement'. Cement and Concrete Research, 34, p. 671-676, 2004.

[14] Libre, N.A.; Khoshnazar, R.; Shekarchi, M. 'Relationship between fluidity and stability of self-consolidating mortar incorporating chemical and mineral admixtures'. Construction and Building Materials, 24, p. 1262-1271, 2010.

[15] Wyrzykowski, M.; Ghourchian, S.; Sinthupinyo, S.; Chitvoranund, N.; Chintana, T.; Lura, P. 'Internal curing of high performance mortars with bottom ash'. Cement \& Concrete Composites, 71, p. 1 - 9, 2016.

[16] ABNT - Associação Brasileira de normas técnicas, NBR NM 52 'Agregado Miúdo Determinação da massa específica e massa específica aparente. ' (2009).

[17] ABNT - NBR NM 23 'Cimento Portland e outros materiais em pó - Determinação da massa específica'. (2001).

[18] ABNT - NBR NM 248. 'Agregados - Determinação da composição granulométrica'. (2003)

[19]ABNT - NBR NM 76. 'Cimento Portland - Determinação da finura pelo método de permeabilidade ao ar (Método de Blaine) '. (1998). 